\title{
First record of Polka-dot ribbonfish Desmodema polystictum (Pisces: Trachipteridae) from Indian waters
}

\author{
P.U. ZACHARIA AND K. KANNAN \\ Central Marine Fisheries Research Institute, PB No.1603, Ernakulam North PO, Cochin-682 018, Kerala, India
}

\begin{abstract}
Polka-dot ribbonfish Desmodema polystictum was recorded for the first time from Indian waters. A single specimen of D. polystictum ( $107 \mathrm{~cm}$ total length and weighing $480 \mathrm{~g}$ ) was collected from Tharuvaikulam landing centre, north to Tuticorin, on the south-east coast of India during September 2010. The distinguishing characters of the species from other species of the family are discussed. Morphometric and meristic characters of D. polystictum are presented in this paper. With the present report, the distribution area of this species now extends to the Indian waters.
\end{abstract}

Keywords: first record, Polka-dot ribbonfish, Desmodema polystictum, Indian waters

Submitted 6 September 2011; accepted 29 November 2011

\section{INTRDDUCTIDN}

The fish of the family Trachipteridae are characterized by long compressed ribbon or tape-shaped body, short head, and narrow mouth (Heemstra \& Kannemeyer, 1986). The pectoral fin is small, pelvic long and fan like in young composed of several rays, absent in adults. Anal fin absent. These fish also have a high dorsal fin that actually occupies the entire length of its back with origin well behind tip of snout. Eyes are large. The family comprises three genera-Trachipterus, Desmodema and $Z u$, altogether with 16 species (Nelson, 2006). Walters (1963) regards $Z u$ as most generalized and Desmodema as most specialized of the three trachipterid genera. These two genera are closely related in the presence of dermal tubercles in large prejuveniles and tubercles and a cutaneous pore system in juveniles and adults.

Desmodema is distinguished from Trachipterus on the basis of nature of the caudal fin (parallel to body axis), the length of gastric caecum and the absence of sharp tipped mid-ventral tubercles (Walters \& Fitch, 1960). In addition to this, in the species of Desmodema there are seven pterygophores before the first and second neural spines and in $\mathrm{Zu}$ and Trachipterus there is a single pterygophore before the first neural spine and nine between the first and second neural spines. Two species have been identified in the genus Desmodema-Desmodema polystictum (Ogilby, 1897) and Desmodema lorum, Rosenblatt \& Butler, 1977. The caudal structure of D. polystictum is unique in Trachipteridae in that all of the caudal rays are borne on the terminal centrum and the hypural of the first ural centrum is rayless. Desmodema polystictum does not have scales; instead tubercles and pores are developed. Young ones

Corresponding author:

P.U. Zacharia

Email: zachariapu@yahoo.com of $D$. polystictum are silvery with profuse dark spotting (polka dotted) but the adults lack spots.

Froese \& Pauly (2010) state that Desmodema polystictum probably has a circumtropical distribution; it was reported from Japan, Taiwan (Shen, 1993), Philippines, Australia, New Zealand (Paulin et al., 1989); Western Pacific (Ogilby, 1897) and $16^{\circ} 11^{\prime} \mathrm{N}$ to Namibia (Aguiar \& Quéro, 1990); South Africa in the eastern Atlantic; Florida, USA (Moore et al., 2003); Cuba (Robins \& Ray, 1986) in the western Atlantic and recently from depths of $500 \mathrm{~m}$ in the western Pacific (Mundy, 2005). Bauchot \& Bianchi (1984) have reported the capture of a single specimen of $D$. polystictum at $72 \mathrm{~m}$ depth from the North Indian Ocean between $24^{\circ} 01^{\prime} \mathrm{N}$ and $66^{\circ} 32^{\prime} \mathrm{E}$. The species has hitherto not been reported from the Indian waters and the present account is the first record of this species from these waters.

\section{MATERIALS AND METHDDS}

A single specimen (107 cm total length and weight $480 \mathrm{~g}$ ) of Desmodema polystictum (Ogilby, 1897) was collected (Figure 1) from Tharuvaikulam landing centre $\left(8^{\circ} 53^{\prime} 42^{\prime \prime} \mathrm{N}\right.$ $\left.78^{\circ} 09^{\prime} 60^{\prime \prime} \mathrm{E}\right)$ north to Tuticorin on the south-east coast of India (Figure 2) on 16 September 2010 and identified based on the available literature (FAO, 1984) and FishBase (Froese \& Pauly, 2010). The specimen was deposited in the National Marine Biodiversity Referral Museum at the Central Marine Fisheries Research Institute, Kochi (ref. no. GB.23.6.1.1). The fish was caught in a mechanized drift gill net (Paruvalai) boat, at a depth of 150-400 $\mathrm{m}$ while conducting 'thangal fishing' (stay-over fishing by large mesh sized gillnets) for 3-5 days. All counts and measurements were taken following Masuda et al. (1984). The morphometric and meristic characters of the present specimen are given in Table 1. 


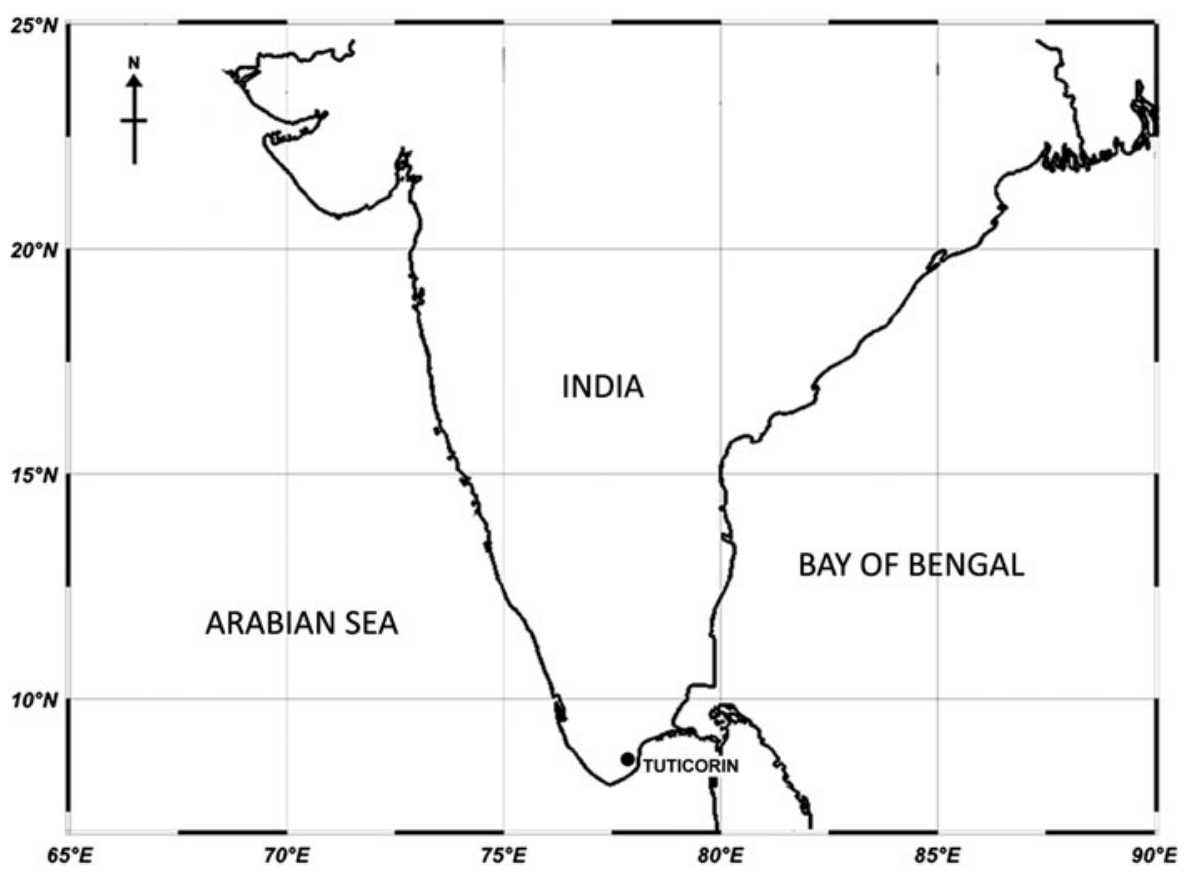

Fig. 1. Map of India showing the location of Tuticorin, the place of collection of the present specimen.

\section{RESULTS}

\section{SYNONYMS}

Desmodema polystictum (Ogilby, 1898)

Desmodema polystictum (Ogilby, 1897); Yabe in Amaoka et al., 1983:127, 202; Heemstra \& Kannemeyer, 1984, Annals of the South African Museum 94: 15; Mundy, 2005, Bishop Museum Bulletins in Zoology 6: 237.

Trachypterus deltoideus Clark, 1938, Proceedings of the California Academy of Sciences 22: 180 (Rurutu Island, Austral Islands).

Trachypterus misakiensis, Tanaka, 1908, Journal of the College of Science, Imperial University 23: 52, pl. 4 (figure 2) (Misaki, Sagami Sea, Japan).

Trachypterus jacksoniensis polystictus Ogilby, 1898, Proceedings of the Linnean Society of New South Wales 23: 649 (off Newcastle, New South Wales, Australia).
Trachipterus woodi Smith, 1953, The sea fishes of southern Africa: 504, figure 264b (Xora River mouth, Transkei).

\section{DESCRIPTION OF THE SPECIMEN}

Body strongly compressed laterally, dorsal spines nil, soft rays 121; post-anal portion of body narrowing into a whip-like tail. Seven pterygophore before first neural spine and one or two pterygophore between first and second neural spines. First pterygophore closely applies to back of skull, no predorsal bones. Caudal fin well-developed, 4-10 unbranched rays parallel to axis of tail. All caudal rays borne on last ural centrum. No ventral caudal lobe. Fin rays with a lateral row of small spines, spines weak or absent on posterior pelvic rays, middle caudal rays and pectoral rays. Each dorsal ray anterior to elongated tail portion of body with a single laterally directed stout spine on either side of the base. Lateral line ends at caudal base, lateral-line scales with a pair of spines. Skin with cartilaginous tubercles and pierced by numerous pores which seems to be pores of the lateral line which is in agreement with Walters (1963). Teeth restricted to one to four in

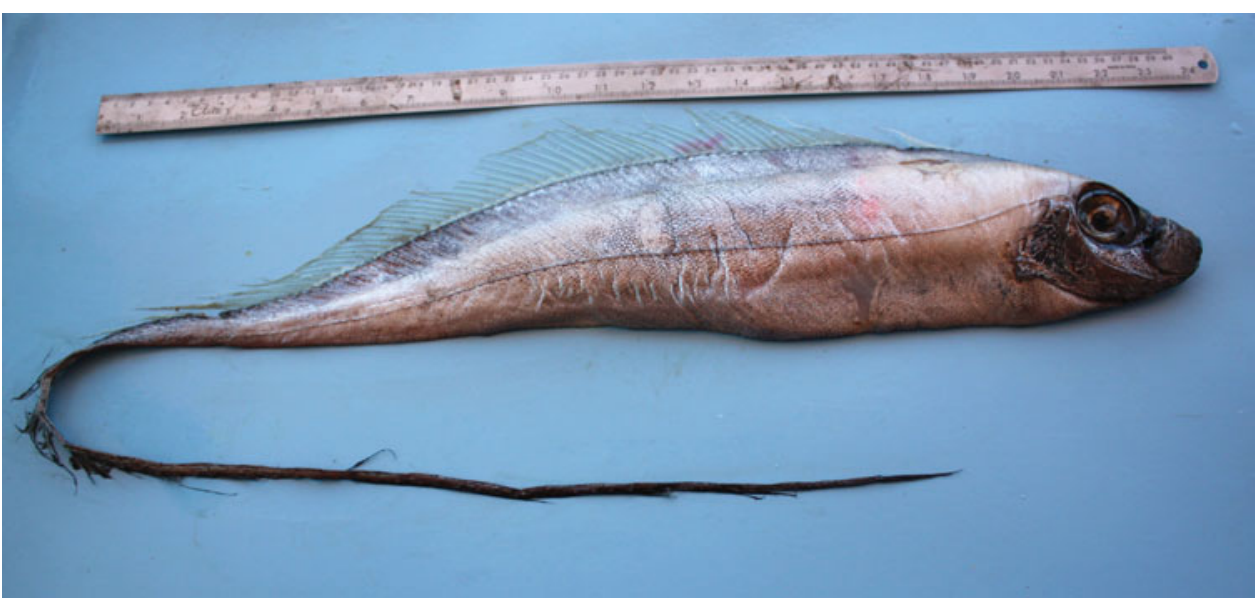

Fig. 2. Desmodema polystictum, $107 \mathrm{~cm}$ total length, caught off Tuticorin south-east coast of India. 
Table 1. Morphometric and meristic measurements of present specimen of Desmodema polystictum (Ogilby, 1897) compared with the measurements given in FishBase (Froese \& Pauly, 2010).

\begin{tabular}{|c|c|c|c|}
\hline \multirow[t]{2}{*}{ Characters } & \multirow[t]{2}{*}{ Measurements (cm) } & \multicolumn{2}{|l|}{ Ratios } \\
\hline & & Present specimen & Referred specimen \\
\hline \multicolumn{4}{|l|}{ Morphometric counts } \\
\hline Total length (TL) & 107 & 107 & 107.5 \\
\hline Head length (HL) & 9.8 & $9.1 \%$ of TL & $8.6 \%$ of TL \\
\hline Body depth & 11.5 & $10.7 \% \mathrm{TL}$ & $12.6 \%$ of TL \\
\hline Pre-dorsal length & 7.5 & $7.0 \%$ of $\mathrm{TL}$ & $6.2 \%$ of TL \\
\hline Snout length & $3 \cdot 3$ & $33.7 \%$ of $\mathrm{HL}$ & \\
\hline Pre-pectoral length & 7.4 & $6.9 \%$ of $\mathrm{TL}$ & $8.5 \%$ of TL \\
\hline Eye diameter & 3.8 & $38.8 \%$ of $\mathrm{HL}$ & $35.8 \%$ of $\mathrm{HL}$ \\
\hline Pre orbital length & 3.7 & $30.6 \%$ of $\mathrm{HL}$ & $28.4 \%$ of $\mathrm{HL}$ \\
\hline Pre-dorsal fin length & 10.5 & & \\
\hline \multicolumn{4}{|l|}{ Meristic counts } \\
\hline Pectoral fin rays & & 14 & 14 \\
\hline Dorsal fin rays & & 121 & 121 \\
\hline Caudal ray & & 8 & 8 \\
\hline Gill rakers (total) & & 12 & $11-13$ \\
\hline —on upper limb & & 3 & $2-3$ \\
\hline —on lower limb & & 9 & $9-10$ \\
\hline
\end{tabular}

each pre-maxilla and two enlarged, recurved fangs on mandible, one on either side of symphysis. Rakers of upper limb with few teeth. Pseudobranch well developed.

\section{DISCUSSIDN}

The present specimen is identified as D. polystictum due to its short snout (smaller than eye diameter) and eight numbers of caudal rays (Table 1 ) whereas $D$. lorum has a longer snout (greater than eye diameter) and six numbers of caudal rays. Desmodema lorum appears to be restricted to the northern Pacific region, whereas $D$. polystictum is broadly distributed in the tropical Pacific and in the South African waters. The northern and southern most records of this species are in areas influenced by warm currents (Rosenblatt \& Butler, 1977). Desmodema lorum is mostly distributed in the cooler waters of the North Pacific. Desmodema polystictum distribution in the Atlantic rests on the records of Leapley (1953) and Walters (1963) and also from the central and southern Atlantic. The morphometric and meristic measurements agree well with the characters given by Heemstra in FishBase (Froese \& Pauly, 2010) and Ogilby (1897).

The present report is significant in the sense that even though D. polystictum is considered as circumtropical, a huge gap existed in the distribution of this species. The distribution range of this species until this record was made extended from the Pacific Ocean to Atlantic Ocean and Northern Indian Ocean. With the present report, the distribution range of this species now extends to the Indian waters but may be considered as rare occurrence only.

\section{ACKNDWLEDGEMENTS}

The authors wish to express their gratitude to the Director, Central Marine Fisheries Research Institute (CMFRI), Cochin for facilities and the Scientist in Charge, TRC of CMFRI, Tuticorin for encouragement. The authors are thankful to Professor Karsten E. Hurtle, of the Museum of Comparative Zoology, Harvard University, Massachusetts for providing materials and literature for identification of the specimen and Smt Rekha J. Nair, Scientist, CMFRI for help in collection of literature.

\section{REFERENCES}

Aguiar A. and Quéro J.-C. (1990) Trachipteridae. In Query J.C., Hureau J.C., Karrer C., Post A. and Saldanha L. (eds) Check-list of the fishes of the eastern tropical Atlantic (CLOFETA). Volume 2. National Museum of New Zealand Miscellaneous Series No. 19. Lisbon: JNICT; Paris: SEI; and Paris: UNESCO, pp. 647-649.

Bauchot M.L. and Bianchi G. (1984) First record of Desmodema polystictum (Ogilby, 1897) in the North Indian Ocean. Cybium 8, 96-98.

FAO (1984) Species identification sheets for fishery purposes. Western Indian Ocean (Fishing Area 51), Volume 4. Rome: FAO.

Froese R and Pauly D. (eds) (2010) FishBase. www.fishbase.org, version (accessed November 2010).

Heemstra P.C. and Kannemeyer S.X. (1986) Trachipteridae. In Smith M.M. and Heemstra P.C. (eds) Smiths' sea fishes. Berlin: SpringerVerlag, pp. 399-402.

Leapley W.T. (1953) First record of the ribbonfish, Trachipterus trachyurus, from the mainland of North America. Copeia 1953, 236.

Masuda H., Amaoka K., Araga C., Uyeno T. and Yoshino T. (1984) The fishes of the Japanese Archipelago. Volume 1. Tokyo: Tokai University Press, 437 pp. (text), 370 pls.

Moore J.A., Hartel Karsten E., Craddock J.E. and Galbraith J.K. (2003) An annotated list of deepwater fishes from off the New England region, with new area records. Northeastern Naturalist 10, 159-248.

Mundy B.C. (2005) Checklist of the fishes of the Hawaiian Archipelago. Bishop Museum Bulletins in Zoology 6, 1-704.

Nelson J.S. (2006) Fishes of the world. 4th edition. New York: John Wiley and Sons Inc, $624 \mathrm{pp}$.

Ogilby J.D. (1897) On a Trachypterus from New South Wales. Proceedings of the Linnean Society of New South Wales 22, 646-659.

Paulin C., Stewart A., Roberts C. and McMillan P. (1989) New Zealand fish: a complete guide. National Museum of New Zealand Miscellaneous Series No. 19, xiv +279 pp. 
Robins C.R. and Ray G.C. (1986) A field guide to Atlantic coast fishes of North America. Boston, MA: Houghton Mifflin Company, 354 pp.

Rosenblatt S.R and Butler J.L. (1977) The ribbonfish genus Desmodema, with the description of a new species (Pisces, Trachipteridae). Fishery Bulletin 5, 843-855.

Shen S.C. (ed.) (1993) Fishes of Taiwan. Taipei: Department of Zoology, National Taiwan University, 960 pp.

Walters V. and Fitch J.E. (1960) The families and genera of lampridiform (Allotriognath) suborder Trachipteroidei. California Fish and Game $46,441-451$. and

Walters V. (1963) The trachipterid integument and an hypothesis on its hydrodynamic function. Copeia 1963, 260-70.

\section{Correspondence should be addressed to:}

P.U. Zacharia

Central Marine Fisheries Research Institute

PB No.1603, Ernakulam North PO

Cochin-682 018, Kerala, India

email: zachariapu@yahoo.com 